\title{
Editorial
}

\section{Form and substance of tax harmonisation}

\author{
Barry Bracewell-Milnes, Banstead, United Kingdom
}

At the meeting of the European Community Council of Ministers in September 1988, the only non-Commission paper on tax harmonisation was contributed by Chancellor of the Exchequer Nigel Lawson. The European Commission was arguing for the harmonisation of indirect taxes through the alignment of the rates at which they are charged; Lawson was arguing for their harmonisation through competition between tax jurisdictions.

This is not so much a professional dispute as a question of tax policy. Harmonisation of tax rates as proposed by the Commission tends to increase tax rates or prevent their reduction. This is because high tax rates imposed by a Member State are a problem only for that Member State, which risks losing business and even tax revenue through competition from lower-tax regimes elsewhere in the Community. Low tax rates, on the other hand, affect higher-tax regimes throughout the Community and thus involve the Commission in its role as the champion of protection - the protection of high-tax regimes against their low-tax competitors. If it were not for this motive of protection, why should the harmonisation of tax rates be considered necessary or even desirable? Federal harmonisation of State sales taxes has not been considered necessary or desirable in the United States; so why should harmonisation of indirect tax rates be necessary between the twelve sovereign Member States of the European Community?

Similarly, the harmonisation of tax bases between Member States otherwise than by competition is not necessary either. The bases of State sales taxes and taxes on company profits are not harmonised in the United States otherwise than by competition between tax jurisdictions, and the absence in the United States of harmonisation from the top down has created no problems for tax bases any more than for tax rates. Switzerland is another example of a prosperous Federal State without centrally imposed harmonisation - a telling example - since Switzerland is smaller than many unitary States.

The European Commission has sought the form of tax harmonisation and negelected the substance: even if the form of tax harmonisation were achieved to the Commission's satisfaction, the substance would be as far away as ever. The form of harmonisation is the alignment of tax rates and bases; the substance is compatibility or peaceful co-existence between different tax structures. Two examples will suffice. First, structural differences between the tax treatment of pensions in different tax jurisdictions were the subject of a seminar at the 1988 Congress of the International Fiscal Association in Amsterdam: in particular, most countries relieve pension contributions and tax the pensions, but Germany exempts the pensions having granted no relief on the contributions. Structural mismatches of this kind have formed the staple fare of IFA Congresses over many years: the solutions to these problems cannot (or can hardly) be achieved unilaterally and require some form of harmonisation through international cooperation. As a second example, John Chown has pointed out in a paper 'Company Tax Harmonisation in the EEC' (published earlier this year by the Institute of Directors, London) that the Commission's draft directives on company taxation have not touched the central problem of the interplay of international and economic double taxation when dividends are paid in one Community Member State out of profits earned in another; this problem is particularly acute for the smaller Member States, since international companies resident in these States earn a relatively large proportion of their income abroad.

Discussions at International Fiscal Association Congresses over many years indicate that there are generally no easy or tidy solutions to structural mismatches between tax systems of the kind illustrated above. This is nevertheless an area where the Commission could make a real and perhaps indispensable contribution to economic integration and prosperity through substantive tax harmonisation. It is therefore regrettable that the Commission has generally neglected this difficult but necessary work in favour of the easier but unnecessary business of formal harmonisation through the alignment of tax rates and bases. 